\section{ESTRUCTURAS DESPLEGABLES PARA ACTIVIDADES LÚDICAS}

\section{DEPLOYABLE STRUCTURES FOR FESTIVE RECREATIONAL ACTIVITIES}

\author{
Juan Bautista Pérez Valcarcel \\ Manuel Freire Tellado \\ Manuel Muñoz Vidal
}

Boletín Académico.

Revista de investigación y arquitectura contemporánea.

Escola Técnica Superior de Arquitectura.

Universidade da Coruña.

ISSN 0213-3474

eISSN 2173-6723

http://revistas.udc.es/index.php/BAC Número 9 (2019) | Páginas 129-146

DOI: https://doi.org/10.17979/ bac.2019.9.0.4635

Fecha de recepción: 30/10/2018

Fecha de aceptación: 21/05/2019

Este trabajo está autorizado por una

Licencia de Atribución de Bienes

Comunes Creativos (CC) 3.0

\section{Resumen}

El artículo hace una revisión de distintas propuestas que se han desarrollado para las actividades de ocio o intercambio comercial, como ferias o mercadillos. Son construcciones en las que la transportabilidad, ligereza y facilidad de erección son determinantes. Se proponen algunas soluciones novedosas de estructuras desplegables, que tienen unas características muy adecuadas para estas funciones. Se hace un somero repaso de las cubiertas textiles y los sistemas de plegado conjunto con el paquete de barras. La tipología analizada es la de módulos oblicuos, poco analizada hasta el presente, y de manera especial, sombrillas, cubiertas a dos aguas y cúpulas piramidales. Se considera que son tres tipologías de gran utilidad para construir recintos transportables, sencillos y eficientes para el desarrollo de actividades lúdicas y de pequeño comercio. También son fácilmente adaptables a situaciones de emergencia, objeto principal de nuestra investigación.

\begin{abstract}
The paper reviews some different facility proposals developed for leisure activities or commercial exchange, such as fairs or markets, proposals for which the portability, lightness and ease of erection are determining conditions. Deployable structures suit very well these requirements, and some novel solutions of them are proposed. A brief review of the fabric covers, the folding systems of the textile cover and the bundle of bars is carried out. The typology of deployable structures with oblique modules is analysed, paying special attention to umbrellatype structures, pitched roofs and pyramidal domes. The three previous ones are considered types of great utility to construct transportable, simple and efficient enclosures for the development of leisure activities and of small commerce. They are all'sotreasily adaptable to emergency šituations, the main object of our research.
\end{abstract}

\section{Palabras clave}

Estructuras desplegables, estructuras ligeras, arquitectura efímera, arquitectura del ocio, construcciones provisionales, edificaciones de emergencia

\section{Keywords}

Deployable structures, lightweight structures, ephemeral architecture, leisure architecture, temporary buildings, emergency buildings 


\section{Introducción}

Desde el Neolítico, la humanidad se ha debatido entre dos formas de vida contrarias y a veces en conflicto: sedentaria y nómada. Esto se refleja en la arquitectura, fija, estable y con voluntad de permanencia en el caso de las civilizaciones sedentarias, y ligera, transportable y efímera en el caso de las civilizaciones nómadas.

Lógicamente siempre hay elementos o factores de confluencia. Un caso interesante son las construcciones transportables usadas como recintos de intercambio en las civilizaciones sedentarias: comercio y diversión pueden implicar un cambio de lugar y necesitan construcciones transportables propias de la vida nómada. Es la vida que aún llevan los feriantes, quienes proporcionan productos y diversiones a distintos asentamientos sedentarios.

Estas necesidades funcionales precisan su propia arquitectura, que muchas veces adopta sistemas que provienen de una realidad paralela como es la guerra. Un ejército en movimiento necesita un alojamiento con las características de transportabilidad y ligereza, los rasgos específicos de este tipo de construcciones.

Una de las mejores definiciones de las prestaciones requeridas se encuentra en el cuento del príncipe Ahmed en "Las Mil y Una Noches". El sultán de la India consigue que el hada Pari Banu le facilite algo excepcional: "[...] una tienda tan ligera que un solo hombre pudiera transportarla en la palma de la mano y lo suficientemente grande para que cupiera en ella mi corte, mi ejército y mi campamento". Es una excelente definición de una solución arquitectónica óptima para estos usos.

En este artículo se aportan algunas de las soluciones que se han analizado a través del proyecto de investigación CODEMOSH en el que trabaja nuestro grupo $^{1}$. Su objeto es erigir cubiertas ligeras que puedan transportarse en un paquete compacto y desplegarse cubriendo un recinto de gran tamaño. No caben en la palma de la mano ni albergan un ejército,

\section{Introduction}

Since the Neolithic Age, Mankind is torn between two opposing and sometimes conflicting forms of life, the sedentary and nomadic. This confrontation is reflected in their architecture: fixed, stable and willing to stay in the case of sedentary civilizations; light, transportable and ephemeral in the case of nomadic civilizations.

Logically there are always elements or factors of confluence. An interesting case is the transportable constructions used as interchange spaces in the sedentary civilizations: commerce and entertainment can imply changes on their location and need the typical transportable constructions of the nomadic life. It is, even nowadays, the way of life of carnies, which provide goods and entertainment to different sedentary settlements.

The functional needs indicated above require their own architecture, which often adopts systems that come from a parallel reality such as war: an army in motion needs housing with the characteristics of portability and lightness, which are also specific requirements of buildings for playful activities.

One of the best definitions of the required services is found in Prince Ahmed's tale in "The Thousand and One Nights". The Sultan of India gets the fairy Pari Banu to provide something exceptional: "[...] a tent so light that one man could carry it in the palm of his hand and big enough to fit my court, my army and my camp." The previous quote is an excellent definition of an optimal architectural solution for these uses.

This paper presents some of the solutions analysed at the CODEMOSH research project, in which our group is working ${ }^{1}$, with the aim of erecting light covers that can be transported in a compact package and deployed covering a large enclosure. They do not fit in the palm of the hand nor shelter an army, but it is 
pero es lo más próximo que puede conseguirse sin la ayuda de la magia.

\section{La arquitectura del ocio: Soluciones fijas y transportables}

La arquitectura del ocio supone una respuesta a situaciones lúdicas que pueden ser periódicas u ocasionales. En el primer caso se emplean construcciones fijas como pueden ser las casetas para romerías (Fig. 01), palcos de música o escenarios fijos, habituales en los campos de la fiesta en el rural gallego. Sin embargo, las estructuras ligadas a estos usos son mayoritariamente efímeras, plegables o desmontables que desaparecen pasado el evento. Construcciones como carpas (circos, puestos de pulpo, eventos gastronómicos, bodas, conciertos, etc.) o casetas (mercadillos, puntos de información, etc.) son siempre útiles e imprescindibles en climas húmedos. Configuran un grupo de estructuras con luces muy diferentes, pero con similares necesidades de versatilidad, transportabilidad, ligereza y rapidez de montaje y desmontaje, pero con exigencias de resistencia y rigidez menores que las estructuras permanentes.

En base a su estrategia de puesta en obra, estas construcciones se clasifican en dos tipos principales, plegables y desmontables. Las primeras configuran el recinto habitable al abrirse; las segundas exigen sencillas labores de montaje en seco. Un paraguas y una the closest thing that can be achieved without the help of magic.

\section{The architecture of leisure: settled versus transportable solutions}

The architecture of leisure is a response to playful situations that can be periodic or occasional. In the first case, permanent constructions are used, such as the stands for pilgrimages (Fig. 01), music boxes or fixed stages, common in the popular party places in rural Galicia. However, the facilities linked to these uses are mostly ephemeral, collapsible or removable, disappearing after the event. Constructions like tents (circuses, gastronomic events, weddings, concerts, etc.), stall or stands (temporary markets, information points, etc.), always useful, are essential in humid climates. They constitute a group of structures with very different spans, but with similar requisites of versatility, portability, lightness and speed of assembly and disassembly, but with lower resistance and rigidity requirements than permanent structures.

According to their putting into service strategy, these structures are classified into two main types: folding constructions and demountable constructions. The structures of the first group make up the habitable space when they are opened; those of the second one require simple

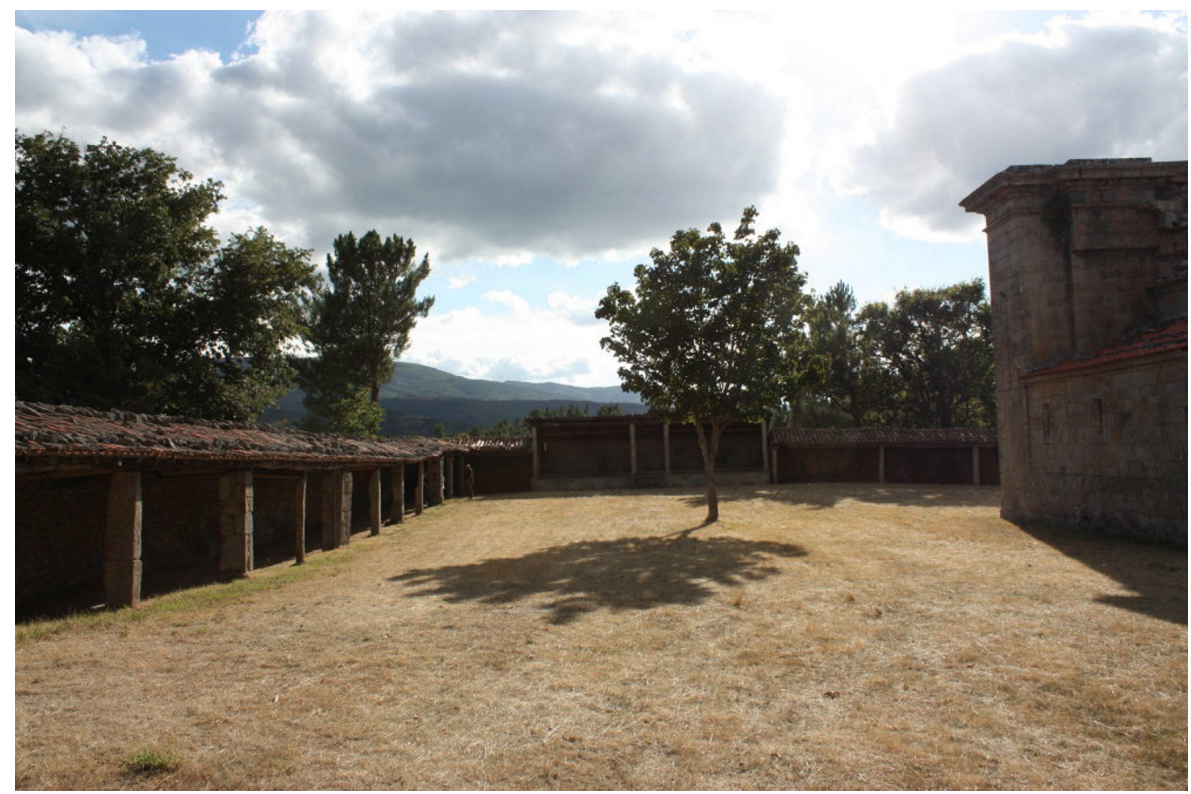

01. Recinto del santuario de Cadeiras. Sober (Lugo).

01. Enclosure of the Cadeiras sanctuary. Sober (Lugo) 
tienda de campaña ilustran ambos conceptos. Las primeras minimizan el tiempo de montaje imponiendo exigencias al diseño y a la fabricación, más estrictas. Las segundas precisan una tecnología mucho más sencilla.

Las aleaciones ligeras, los nuevos materiales de cobertura y el desarrollo de los procesos de fabricación han dado impulso a las estructuras desplegables, hoy frecuentes en puestos de venta de fiestas, ferias y mercadillos, carreras de todo tipo y soportes de cartelería. Se trata en todo caso de elementos de luces reducidas con piezas de escasa complejidad.

Si el espíritu de los tiempos es la transformabilidad, los mismos espacios pueden ser soporte de usos rápidamente mutables, en los que los tiempos de espera o de montaje son vistos como un problema. El criterio de plegabilidad conduce a mínimos tiempos de transformación y maximiza la posibilidad de uso del espacio.

\section{Soluciones textiles con estructuras ligeras}

Las soluciones con elementos textiles son probablemente las más antiguas por su sencillez y de hecho son comunes en todas las civilizaciones. Una de las más conocidas es la papilio romana, una tienda de piel de cabra que servía de alojamiento a ocho legionarios. A lo largo de la historia se han modificado los materiales, pero la forma básica sigue siendo similar.

Las estructuras textiles son base de muchas de las soluciones de la arquitectura de ferias y mercadillos. No nos extenderemos en su estudio, puesto que es realmente difícil aportar novedades en un camino tan trillado. Con todo, la mayor parte de las soluciones que se proponen van a precisar una cubierta textil, como material más idóneo ${ }^{2}$.

Las soluciones basadas únicamente en elementos textiles tienen fuertes limitaciones resistentes. Cuando se desean mayores prestaciones es necesario complementar el textil con otros elementos como cables o barras metálicas ${ }^{3}$. dry-assembly work: an umbrella and a tent illustrate both concepts. The first type of constructions minimizes assembly time by imposing stricter design and manufacturing requirements; the second one requires a much simpler technology.

The light metal alloys, the new covering materials and the development of the manufacturing processes have given impetus to the deployable structures, now frequent in stalls selling parties, fairs and markets, races of all kinds and signage stands. In any case, these constructions cover reduced spans and are made up with pieces of low complexity.

If transformability is the spirit of our time, the same spaces must be able to support rapidly changing uses, where waiting times or assembly times are a problem. The folding criterion leads to minimum transformation times and maximizes the possibility of using the space.

\section{Textile solutions with lightweight structures}

The solutions with textile elements are probably the oldest for their simplicity and in fact are common in all civilizations: one of the best known is the Roman papilio, a goatskin tent that served as accommodation for eight legionaries. Throughout history the materials have been modified, but the basic form remains similar.

Fabric structures are the basis of many of the architecture solutions of fairs and markets. We will treat them briefly, since it is hard to contribute something new in such a trite field. However, most of the proposed solutions will require a textile cover, as it is the most suitable system ${ }^{2}$.

Solutions based only on textile elements have big strength limitations. When greater capabilities are demanded it is necessary to complement the textile cover with other elements such as cables or metal bars ${ }^{3}$. A paradigmatic 
Un elemento paradigmático puede ser el paraguas, una de las estructuras más eficaces y resistentes que existen.

Desde la antigüedad se usan sombrillas para protegerse del sol. Aparecen en relieves egipcios y asirios y son elementos tradicionales cuyo origen y desarrollo es imposible seguir. Una sombrilla se usa con buen tiempo y sus necesidades resistentes son mínimas. En cambio, el paraguas debe ser capaz de resistir con eficacia condiciones atmosféricas muy adversas -lluvia y viento- exigiendo unas prestaciones muy superiores.

Sabemos poco de la historia del paraguas. En el folio 25 verso del Códice de Madrid I de Leonardo aparece un magnífico dibujo de un mecanismo para una sombrilla o paraguas, aunque poco eficaz (Fig. 02). Curiosamente está dibujada con mucho menos detalle la solución buena, con la varilla articulada, como existe en los paraguas modernos ${ }^{4}$. Como es habitual en Leonardo, su invento a medias quedó olvidado, hasta que un desconocido inventor alemán empezó a fabricar paraguas con su forma actual en el siglo XVIII. Pronto otro inventor inglés introdujo las varillas abiertas, dejando el paraguas prácticamente como en la actualidad.

En términos generales podemos entender que la diferencia principal entre la sombrilla y el paraguas se refiere a la tensión de la tela. La sombrilla tiene exigencias resistentes pequeñas, por lo que se despliega sin tensión y las varillas se mantienen rectas. Por el contrario, el paraguas debe funcionar en condiciones adversas, por lo que la tela -con un ancho menor que la distancia entre varillas- se tensa y las varillas se curvan pretensándose, consiguiendo una mayor capacidad resistente (Fig. 03).

Tanto la sombrilla como el paraguas son artefactos individuales. Los intentos realizados para construirlos a escala arquitectónica han sido escasos y siempre como elementos adjetivos en la ciudad. Si se quiere un tamaño mayor, que permita un uso colectivo, se observa que el paraguas mantiene sus ventajas resistentes, pero en general su example is the umbrella, one of the most effective and resistant structures in the world.

Since ancient times, sunshades have been used to protect from the sun. They already appear in Egyptian and Assyrian reliefs: they are traditional elements whose origins and development are impossible to follow. Parasols are used when the weather is fine, and their resistant needs are minimal. However, umbrellas must be able to withstand very adverse atmospheric conditions -rain and wind- demanding a greater performance.

Few things are known on the history of the umbrella. In the folio 25 verso of the Madrid Codex I of Leonardo there is a magnificent drawing of a mechanism for a parasol or umbrella, although the solution is not very effective (Fig. 02). Astonishingly, the right solution, with the articulated rod as in modern umbrellas, is drawn with much lower detail $^{4}$. As usual in Leonardo, his half-invention was forgotten, until an unknown German inventor began to make umbrellas with their current form in the eighteenth century; another English inventor introduced the open rods shortly after, leaving the umbrella practically as it is nowadays.

Broadly speaking it can be pointed out that the main difference between sunshades and umbrellas refers to the stresses suffered by the fabric. Umbrellas have small bearing requirements, so the fabric unfolds stress-free and the rods remain straight. Opposite to them, umbrellas must work in adverse conditions, so that the fabric -which has a width smaller than the span distance between rods, is tensioned and the rods are bent, prestressing the whole, which results in a greater bearing capacity (Fig. 03).

Both the parasol and the umbrella are individual artefacts. The attempts made to build them on an architectural scale have been scarce and always as adjective elements in the city. On the one hand, if a larger size is required, allowing a collective use, it is observed that the umbrella maintains its withstand advantages, however, its deployment will generally

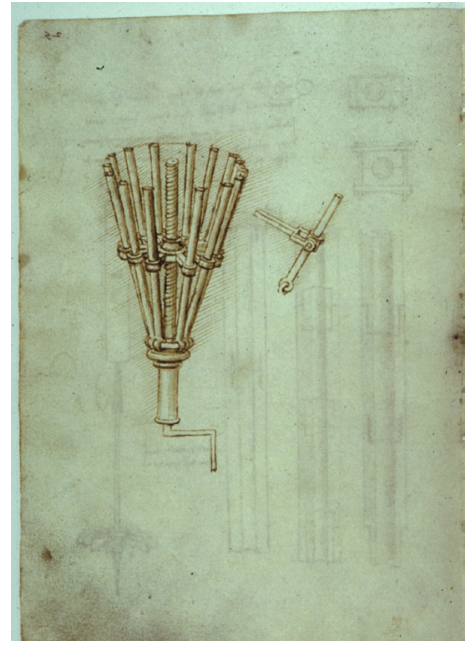

02. Folio 25 verso del Códice de Madrid I de Leonardo.

02. Folio 25 verso of the Madrid Codex I by Leonardo da Vinci. 
03. Comparación entre sombrillas $y$ paraguas.

03. Comparison between parasols and umbrellas. ancrellas.

and umbellas.
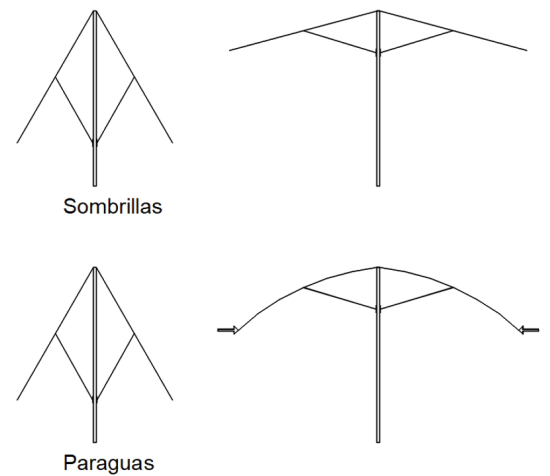

despliegue interferirá con los usuarios. Por el contrario, y a efectos prácticos, las sombrillas desplegables son una solución muy adecuada y un elemento de uso común en ferias y mercadillos.

\section{Soluciones desplegables}

El objeto principal de nuestro estudio son las estructuras desplegables. Son conjuntos de barras, articuladas en sus extremos y en un punto central, que son capaces de plegarse en paquetes compactos para permitir un fácil transporte y ser desplegados cuando sea necesario para cubrir un amplio recinto.

Las primeras propuestas de estructuras desplegables se deben a Pérez Piñero utilizando módulos de haces 5 . En los ańos 80 y 90 se realizaron una serie de interesantes estudios. Se estudiaron ampliamente las estructuras desplegables de aspas ${ }^{6}$, sus condiciones geométricas ${ }^{7}$ y sus elementos constructivos ${ }^{8}$. Hoberman $^{9}$ planteó una serie de interesantes estructuras de despliegue radial y Gantes ${ }^{10}$, You ${ }^{11}$ o Pellegrino ${ }^{12}$ añadieron otros tipos estructurales. Sin embargo, sólo se llegaron a construir unas pocas obras, los pabellones de exposiciones de Pérez Piñero ${ }^{13}$ y Merchán ${ }^{14}$ y la cubierta de la piscina de San Pablo en Sevilla ${ }^{15}$.

Tras un período de escaso desarrollo se han retomado los estudios de estas estructuras. Pueden citarse las tesis doctorales de Temmerman ${ }^{16}$ y Beguiristain ${ }^{17}$ y los trabajos de Popovic ${ }^{18}$, Atake con una curiosa propuesta telescópica ${ }^{19}$ o $\operatorname{Le}^{20}$. Son de destacar dos libros que contienen una amplia referencia a este tipo de estructuras, los de Ishii ${ }^{21}$, que analiza todo tipo de
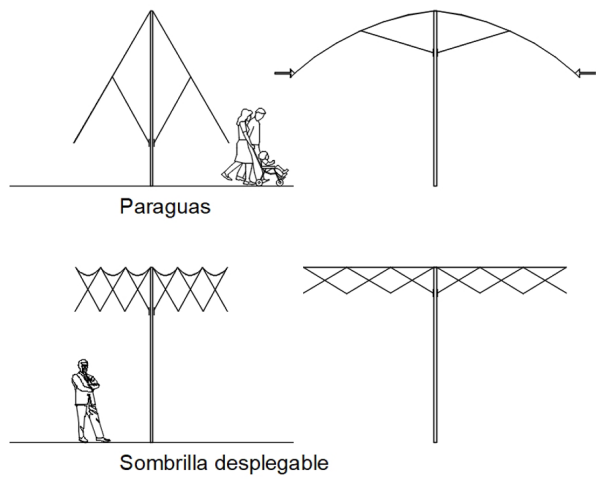

interfere with the users. On the other hand, the deployable parasols do not have this problem, so these stand them as a very suitable solution and a commonly used element in fairs and markets.

\section{Deployable solutions}

Deployable structures are the main object of our study. They are sets of crossed bars, articulated at their ends and linked each other at an intermedium point by a revolute joint, which are capable of folding into compact packages to allow easy transport and be deployed when necessary to cover a large area.

The first proposals for deployable structures are due to Pérez Piñero using bundle modules 5 . In the 1980s and 1990 s a series of interesting studies were carried out: the scissor-like deployable structures ${ }^{6}$, their geometric conditions $^{7}$ and their constructive elements $^{8}$ were studied extensively. Hoberman $^{9}$ raised a series of interesting radial deployment structures and Gantes $^{10}$, You ${ }^{11}$ or Pellegrino ${ }^{12}$ added other structural solutions. However, only a few works were built: the Pérez Piñero's exhibition-pavilion ${ }^{13}$, the Hernández Merchán's one ${ }^{14}$ and the roof of the San Pablo swimming-pool in Seville ${ }^{15}$.

After a period of poor development, studies of these structures have been resumed. We can quote the doctoral theses of Temmerman ${ }^{16}$ and Beguiristain ${ }^{17}$ and the works of Popovič ${ }^{18}$, Atake -with a curious telescopic proposal ${ }^{19}$ - o Lee ${ }^{20}$. It is worth highlighting two books containing a broad reference to this structural type: the Ishii's one ${ }^{21}$, which analyzes all 
estructuras transformables y el de Rivas Adrover $^{22}$, más específico de estructuras desplegables.

Sus aplicaciones potenciales son prometedoras. En general se han diseńado siempre como cubiertas ligeras para edificios de uso público, pero pueden ser utilizados como locales para actividades lúdicas o de ferias, mercadillos, etc. y también como refugios, locales comunes o viviendas provisionales en las zonas donde ha surgido una situación de emergencia.

Las estructuras desplegables con articulaciones tipo tijera se pueden resolver mediante módulos de dos tipos: módulos de aspas formados por tres o cuatro aspas unidas por sus extremos (Fig. 04) o módulos de haces formados por un haz de tres o cuatro barras que se cortan en un punto interior alrededor de un pivote con tres o cuatro pernos. Para las mallas espaciales curvas, tales como bóvedas cilíndricas o cúpulas, estos módulos pueden estar curvados en el espacio ${ }^{23}$.

Los módulos triangulares de aspas son rígidos, pero el resto de módulos no. Con todo, tienen en general un buen comportamiento estructural, como se pudo verificar mediante simulaciones por ordenador. Además, los módulos no rígidos pueden ser reforzados por medio de cables o barras para luces grandes. Para las soluciones propuestas de luces cortas o medias, es suficiente con la cubierta textil.

Toda malla desplegable exige el cumplimiento de una condición esencial, la condición de plegabilidad: types of transformable structures, and Rivas Adrover's text ${ }^{22}$, more specific on deployable structures.

The deployable structures potential applications are promising. They have generally been designed as light roofs in buildings for public use, but they can also be used as premises for leisure activities, fairs or markets, etc. and, at last, as shelters, common premises or temporary housing where an emergency situation takes place.

The Scissor-Hinged Deployable Structures can be built in two ways: employing $\mathrm{x}$-cross modules formed by three or four $\mathrm{x}$-cross elements joined by their ends (Fig. 04) or using bundle modules formed by a set of three or four bars joined together at an inner point around a pivot with three or four bolts. For curved spatial grids, such as cylindrical vaults or domes, these modules can have two different curvatures in $3 \mathrm{D}$ space $^{23}$.

The triangular $\mathrm{x}$-cross modules are rigid, but the others are not. However, all of them generally have a good structural behaviour, as it has been verified by computer simulations. In addition, non-rigid modules can be reinforced by adding cables or bars for large spans. In the case of the proposed solutions, with short or medium spans, the reinforcement provided by the textile cover is enough.

All foldable expandable mesh must fulfill an essential condition, the deployability constraint: the sum of
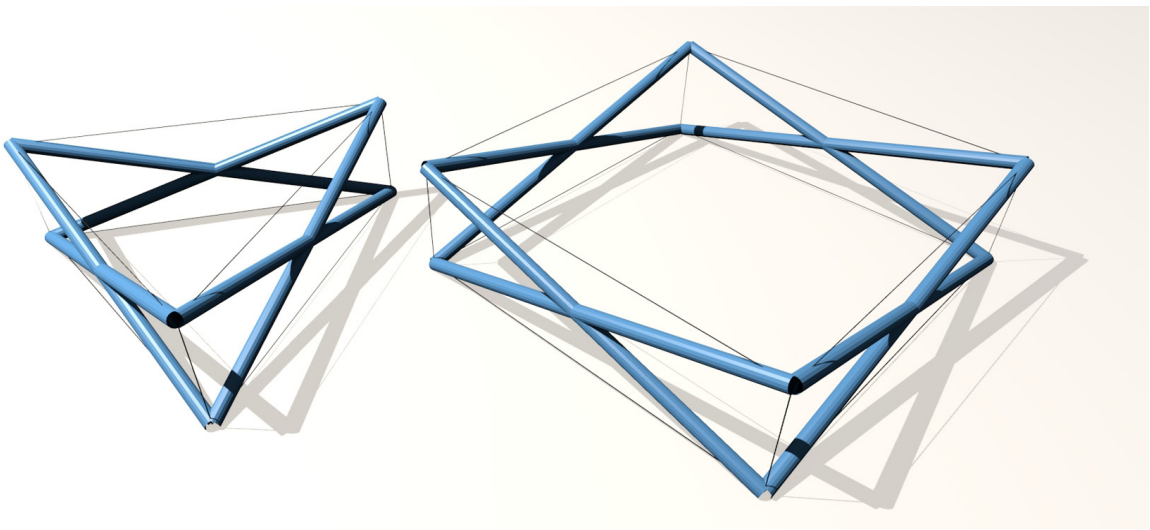

04. Esquema de módulos de aspas, triangulares y cuadrados.

04. Schematic diagram of triangular and square modules of scissors. 
la suma de las longitudes de los tramos de barra que concurren en el mismo nudo ha de ser igual en todas las aspas, de forma tal que la malla pueda plegarse en un paquete compacto. Es una condición muy restrictiva que exige un tratamiento geométrico complejo ${ }^{24}$.

Otra dificultad que añaden estas estructuras es la definición de la longitud de las barras adecuada para permitir la compatibilidad cinemática de plegado y desplegado en todas las posiciones intermedias. En términos generales, los modelos de ordenador han demostrado que, con la excepción de mallas planas, muchas de las estructuras, y especialmente en cúpulas, la compatibilidad geométrica en las posiciones de inicio y fin del despliegue puede ser garantizada, pero no así en posiciones intermedias. Ello obliga a que las soluciones posibles tengan que ser necesariamente aproximadas. Esto que presenta grandes dificultades teóricas, no supone en la práctica un inconveniente insalvable, por cuanto que al tratarse de mecanismos móviles los nudos deben tener unas ciertas tolerancias, lo que permite absorber los posibles problemas de ajuste. Cuando la incompatibilidad es mayor, debe aplicarse una energía adicional durante el proceso de expansión con el fin de forzar la incompatibilidad. Esa energía es devuelta por la estructura, completando de esta manera su despliegue. Tanto los ensayos realizados como la experiencia de la construcción de la cubierta de la piscina de San Pablo en Sevilla con una luz de $30 \mathrm{~m}$ (Fig. 05), han mostrado que estas dificultades teóricas carecen de relevancia práctica ${ }^{25}$. lengths of the semi-scissors coming together in any pair of nodes placed on a folding line should be equal, so that the grid can be folded in a compact package. It is a very restrictive condition that demands a complex geometric treatment ${ }^{24}$.

These structures add another difficulty: the definition of the appropriate length of the bars to allow kinematic compatibility in all the intermediate positions of folding and unfolding. In general terms, computer models have shown that, except for flat meshes, in many structures (especially domes) geometric compatibility can be guaranteed in the initial and final positions of the deployment process, but not in the intermediate positions. Therefore, feasible solutions must necessarily be approximate. This fact, which presents great theoretical difficulties, does not imply an insurmountable inconvenience in practice. When dealing with mobile mechanisms, knots must have certain tolerances, which allow absorbing possible adjustment problems. With greater incompatibilities, additional energy must be applied during the deployment process in order to overcome the incompatibility. This energy is returned by the structure, thus completing its deployment. Both the tests carried out and the experience in the construction of the roof of the San Pablo pool in Seville, which spans $30 \mathrm{~m}$ length (Fig. 05), have shown that these theoretical difficulties lack practical relevance ${ }^{25}$.

05. Piscina de San Pablo durante su construcción. construction.

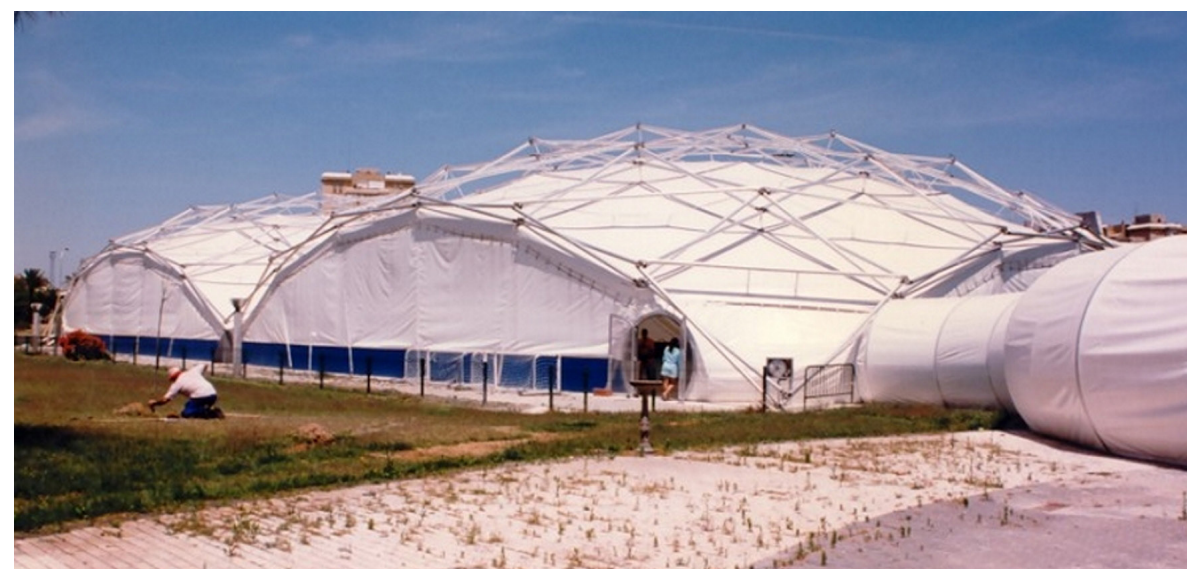




\section{Cubiertas textiles: Sistemas de plegado}

Un aspecto de la mayor importancia en la construcción de este tipo de estructuras radica en la definición de sistemas de autoplegado de la cubierta textil ${ }^{26}$. De no preverlo, la cubierta puede plegar de forma irregular, con lo que al cerrarse las aspas podrían hacer un efecto de cizalla, rompiendo el tejido. El sistema que se ha revelado como el más eficaz es la simple colocación de una cinta que, cuando el textil está colocado en la cara superior, se sujeta a los nudos inferiores y en la zona central de cada recuadro del textil, de forma tal que, al plegarse la estructura, los nudos inferiores tiran del textil hacia abajo y fuerzan su pliegue entre las aspas del módulo plegado. Cuando el textil se coloca en la cara inferior la cinta se cuelga de los puntos altos de la malla. Para garantizar el correcto plegado se tiene que imponer la condición que la suma de longitudes de la cinta y del textil sea igual a la altura del paquete plegado (Fig. 06).

Módulos triangulares

$$
\mathrm{L}_{1}+\mathrm{L}_{2}=\mathrm{L}_{3}+\mathrm{L}_{4}
$$

Módulos cuadrados

$$
\mathrm{L}_{1}+\mathrm{L}_{2}+=\mathrm{L}_{3}+\mathrm{d}_{1}=\mathrm{L}_{5}+\mathrm{d}_{2}
$$

Es una mera condición geométrica que para módulos regulares puede ser fácilmente determinada analíticamente y para módulos irregulares resulta más sencillo resolverla por tanteos. Es conveniente dar cierta holgura a la longitud de la cinta y ajustarla en el montaje.

\section{Textile covers: folding systems}

The definition of the self-folding system of the fabric cover is an aspect of great importance in the construction of this kind of structures ${ }^{26}$. If it is not foreseen the cover could be folded in an irregular way, so that the scissors could perform a shear effect when closing and breaking the textile. The system that has been revealed as the simplest and most effective is setting a tape that, when the fabric is placed on the upper face, is attached to the lower knots and to the central area of each textile box. In such a simple way, when the structure is being folded the lower knots pull the fabric down and force its fold between the blades of the module. When the textile is placed on the underside the tape hangs from the high points of the mesh. When the textile is placed on the underside the tape hangs from the high points of the mesh. The condition that guarantees the correct folding demands that the sum of the lengths of the tape and the textile equals the height of the folded package (Fig. 06).

Triangular modules

$$
\mathrm{L}_{1}+\mathrm{L}_{2}=\mathrm{L}_{3}+\mathrm{L}_{4}
$$

Square modules

$$
\mathrm{L}_{1}+\mathrm{L}_{2}+=\mathrm{L}_{3}+\mathrm{d}_{1}=\mathrm{L}_{5}+\mathrm{d}_{2}
$$

It is a simple geometric condition that can be easily solved analytically with regular modules but when irregular ones it is easier to solve by trial and error. It is convenient to give some slack to the length of the tape and adjust it during the assembly.

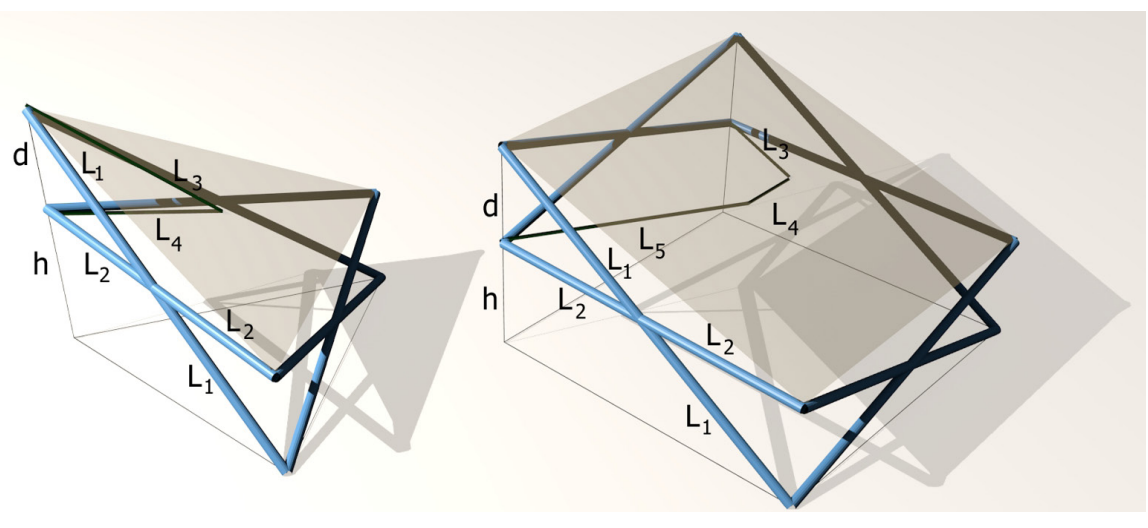

06. Sistemas de autoplegado para cubiertas textiles

06. Self-folding systems for textile covers 


\section{Algunas propuestas}

Para el uso lúdico y ocasional que se propone suele ser suficiente con cubiertas que apoyan directamente sobre el suelo. Se pueden fijar con anclajes simples, puesto que las acciones son reducidas. $Y$ al no tener que integrar el elemento suelo, las soluciones pueden ser más sencillas y económicas.

Nuestro equipo ha desarrollado una amplia investigación durante muchos años, por lo que se han propuesto numerosas soluciones. Dadas las limitaciones de este texto se expondrán varias propuestas con módulos oblicuos, que no habían sido desarrolladas con anterioridad y que pueden aportar soluciones de interés. Estos módulos pueden ser triangulares o cuadrados y tienen la ventaja ańadida de que permiten definir cubiertas inclinadas, lo que es del mayor interés en climas lluviosos. De las posibles soluciones se analizarán tres, sombrillas, cubiertas a dos aguas y cúpulas piramidales, que proporcionan recintos muy adecuados para los usos previstos.

Es necesario definir las condiciones geométricas para determinar las longitudes de las barras, como se observa (Fig. 07).

En mallas planas la solución es trivial. Se consideran como parámetros el canto de la malla h y la apertura del aspa d, resultando

\section{A few proposals}

In the scope of this study, focused on a playful and occasional use, it is usually enough that the covers rest directly on the ground. They can be fixed with simple anchors, as the actions are small in magnitude. Thus, by not having to integrate the ground, the solutions can be simpler and cheaper.

Our team has developed an extensive research over years, where many solutions have been proposed. Given the limitations of this text, several original proposals developed with oblique modules, not developed before and providing interesting solutions are presented below. These modules, which can be triangular or square in shape, have the added advantage of allowing defining inclined roofs, which is of the greatest interest in rainy climates. Three types of the possible solutions will be analysed: parasols, gable roofs and pyramidal domes, which provide very suitable enclosures for the intended uses.

As it is observed (Fig. 07), it is necessary to previously define the geometric conditions to determine the lengths of the bars.

In flat meshes the solution is trivial. The height of the mesh $\mathrm{h}$ and the opening of the scissor $\mathrm{d}$ are considered as parameters, resulting

$$
2 \cdot L_{1}=\sqrt{h^{2}+d^{2}}
$$

Para el despliegue oblicuo interesa definir como parámetros el canto de la malla $\mathrm{h}$ y la apertura del aspa $\mathrm{d}$, pero también la inclinación de la cubierta a. Aplicando el teorema del coseno se pueden calcular las dimensiones de las barras y la altura del paquete cerrado
For the oblique deployment it is interesting to define as parameters the height of the mesh $\mathrm{h}$ and the opening of the scissor d, but also the inclination of the cover $\alpha$. Applying the cosine theorem, the dimensions of the bars and the height of the closed package can be obtained

$$
\begin{aligned}
& L_{1}=\sqrt{\frac{h^{2}}{4}+\frac{d^{2}}{4 \cos ^{2} \alpha}+\frac{2 d \cdot h}{4 \cos \alpha} \cdot \operatorname{sen}^{2} \alpha} \\
& L_{2}=\sqrt{\frac{h^{2}}{4}+\frac{d^{2}}{4 \cos ^{2} \alpha}-\frac{2 d \cdot h}{4 \cos \alpha} \cdot \operatorname{sen}^{2} \alpha}
\end{aligned}
$$



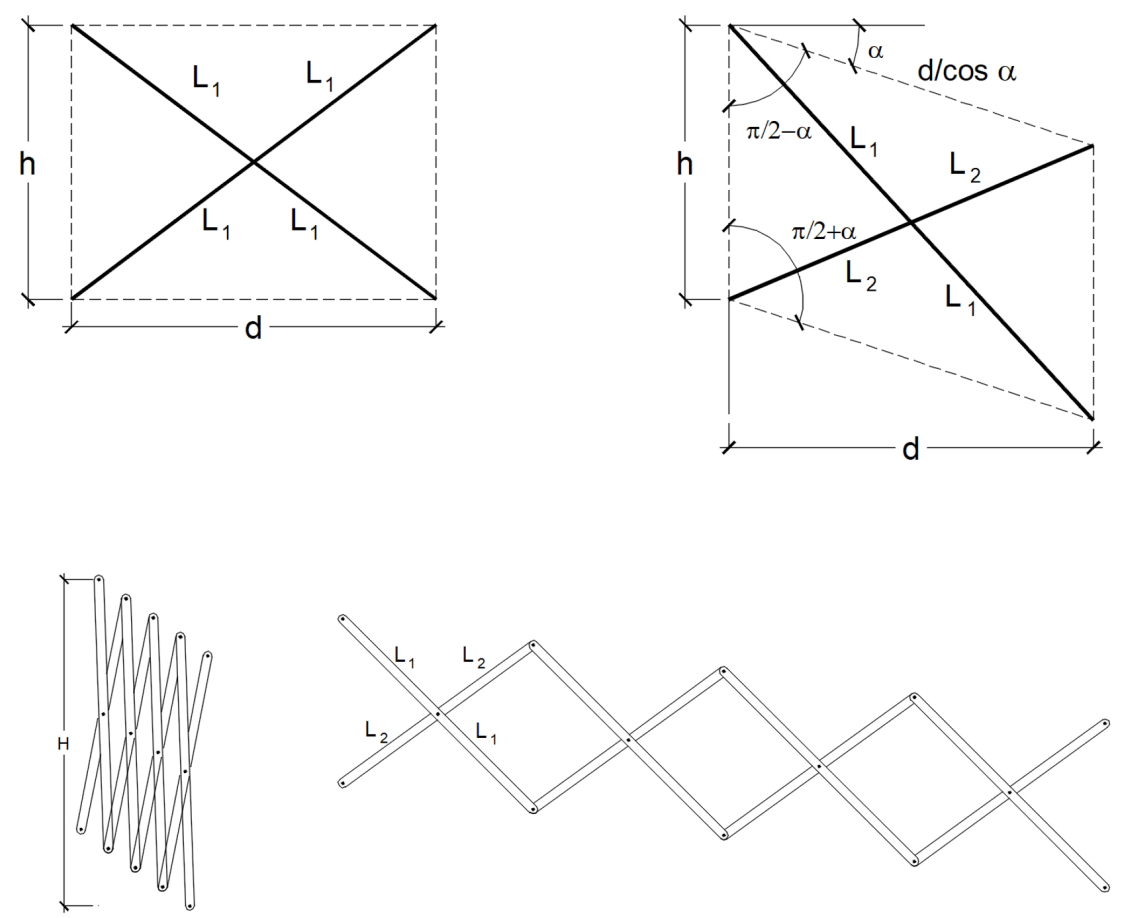

Los módulos oblicuos tienen un problema que es el empaquetamiento de las barras del módulo en posición plegada. En la mayor parte de las estructuras desplegables la altura del paquete compacto es prácticamente la de las barras del módulo. Sin embargo, para módulos oblicuos y considerando $\mathrm{n}$ módulos desde la cumbrera al arranque, la altura del paquete de barras es aproximadamente (Fig. 08).

$$
H=2 \cdot L_{1}+2 \cdot(n-1) \cdot\left(L_{1}-L_{2}\right)
$$

Esto hace que a medida que aumenta el número de módulos y la inclinación de los faldones, el paquete adquiera mayores dimensiones, lo que puede dificultar su transporte. Este es probablemente el problema que ha limitado el estudio de este tipo de estructuras, por otra parte, muy resistentes. Para luces medias como las propuestas, el problema no es relevante.

\subsection{Sombrillas}

Las sombrillas son estructuras sencillas y con un buen comportamiento estructural. Son también un tipo de cubierta muy adecuada para usar una estructura desplegable, puesto que es lógico el deseo de abrirla cuando
07. Esquema de plegado de un módulo oblicuo.

08 Definición de las longitudes de las barras según el despliegue.

07. Folding diagram of an oblique module.

08. Definition of the lengths of the bars according to the deployment.
The oblique modules have the problem of the packing of the module bars in folded position. In most of the deployable structures the height of the compact package is practically equals to that of the bars of the module. However, considering $\mathrm{n}$ oblique modules from the ridge to the bottom, the height of the package of bars is approximately (Fig. 08).
Expression that makes it clear that the greater the number of modules and the inclination of the roofs, the greater the dimensions of the package, which can become difficult to transport. This is probably the problem that has limited the study of this type of structure, on the other hand, very resistant. However, for medium spans like the ones proposed, the problem is not relevant.

\subsection{Sunshades}

Sunshades are simple structures with a good structural behaviour. They are also a very suitable type of roof to be built with a deployable structure, since it is logical to open them when necessary, both by sun and rain, and to fold them 
09. Sombrilla formada por módulos de paraboloide hiperbólico.

09. Parasol formed by hyperbolic paraboloid modules.
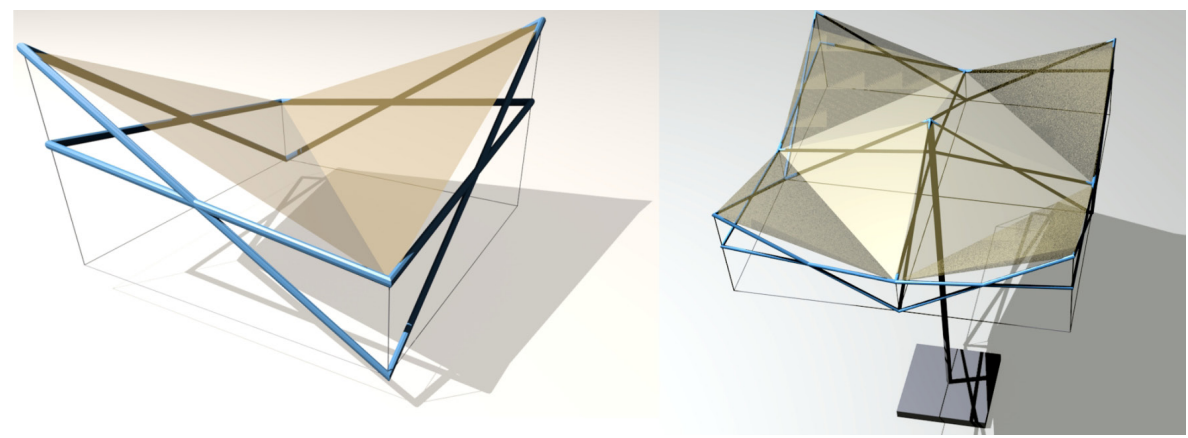

es necesaria, tanto por sol como por lluvia y de plegarla cuando no lo es. Permiten además mallas muy regulares, lo que facilita su construcción al usar módulos de dimensión constante y por otra parte son muy sencillas de cubrir, tanto con cubiertas textiles como con placas rígidas. Ha sido una solución muy usada para terrazas o mercadillos. Un excelente ejemplo es la cubierta de la plaza de la Mezquita del Profeta en Medina, obra de Frei Otto ${ }^{27}$.

Pueden emplearse módulos triangulares, cuadrados prismáticos o incluso cuadrados formando superficies externas de paraboloide hiperbólico (Fig. 09), que tienen la ventaja de una excelente evacuación de aguas. En todos los casos es posible resolver con sencillez las comprobaciones cinemáticas de plegado y desplegado y además las barras son de la misma longitud, lo que facilita su construcción y montaje. La referencia proporciona los datos de diversos estudios y cálculos realizados a raíz de una propuesta para cubrir la plaza de S. Francisco en Sevilla, que no llegó a realizarse $e^{28}$.

\subsection{Cubiertas a dos aguas}

Las cubiertas a dos aguas se pueden conseguir fácilmente con módulos cuadrados oblicuos. Este tipo de módulos carece de rigidez ante movimientos laterales, por lo que estas estructuras precisan de sistemas de arriostrado, normalmente cables o barras en grandes estructuras. Para luces pequeńas o medias la propia cubierta textil supone un arriostramiento suficiente (Figs. 10 y 11).

El comportamiento estructural de este tipo de cubiertas mejora considerablemente si se fijan al mástil los dos nudos que when it is not. They also allow very regular meshes, which makes their construction easy by using modules of constant dimension. In addition, they are very simple to cover, both with textile covers and with rigid plates. That is why sunshades have been a widely used solution for terraces and temporary markets: an excellent example is the cover of Piazza of the Prophet's Holy Mosque in Madinah, in which Frei Otto intervened $^{27}$.

Parasols can be built using triangular or squared prismatic modules or even square modules generating surfaces of extrados shaped as hyperbolic paraboloid (Fig. 09), which have the advantage of providing an excellent water evacuation. It is possible in all the former cases to solve with simplicity the folding and unfolding kinematic checks using bars of the same length, which facilitates its construction and assembly. The attached reference contains the data of various studies and calculations made to cover the Piazza of San Francisco in Seville, which remains unbuilt ${ }^{28}$.

\subsection{Gable roofs}

Gable roofs can be easily achieved with oblique square modules. This type of modules lacks rigidity before lateral movements, so these structures require stiffening systems, usually cables or bars in large structures. For small or medium span, the textile cover itself assumes enough stiffening (Figs. 10 and 11).

The structural behaviour of this type of roof improves considerably if the two linkages on the mast are fixed to 
concurren en él. Para ello es necesario diseñar elementos específicos que permitan que el nudo superior permita la articulación y el inferior deslice sobre el mástil hasta quedar bloqueado en su posición final. Un sistema sencillo similar al tope del paraguas es suficientemente eficaz.

\subsection{Cúpulas piramidales}

Las cúpulas desplegables tienen una buena capacidad para permitir cubrir espacios grandes con un coste estructural razonable. Por ello es una de las estructuras desplegables más utilizada, dentro de la escasa difusión de este tipo de estructuras.

Son posibles dos tipos de cúpulas, las formadas por módulos triangulares y las formadas por módulos cuadrados. En el caso de las cúpulas de módulos triangulares se ha propuesto distintas it. In order to do this, it is necessary to design specific elements that allow both the rotation of the upper linkage and the sliding on the mast of lower one until its final position where it will be locked. A simple system, similar to the top of the umbrella, is sufficiently effective.

\subsection{Pyramidal domes}

The deployable domes have a good capacity to cover large spaces with a reasonable structural cost. For this reason, it is one of the most used deployable structures, within the scarce diffusion of this type of structure.

These domes can be built by using triangular modules or by using squared ones. In the first case -domes formed by triangular modules- different solutions have been proposed based either on the
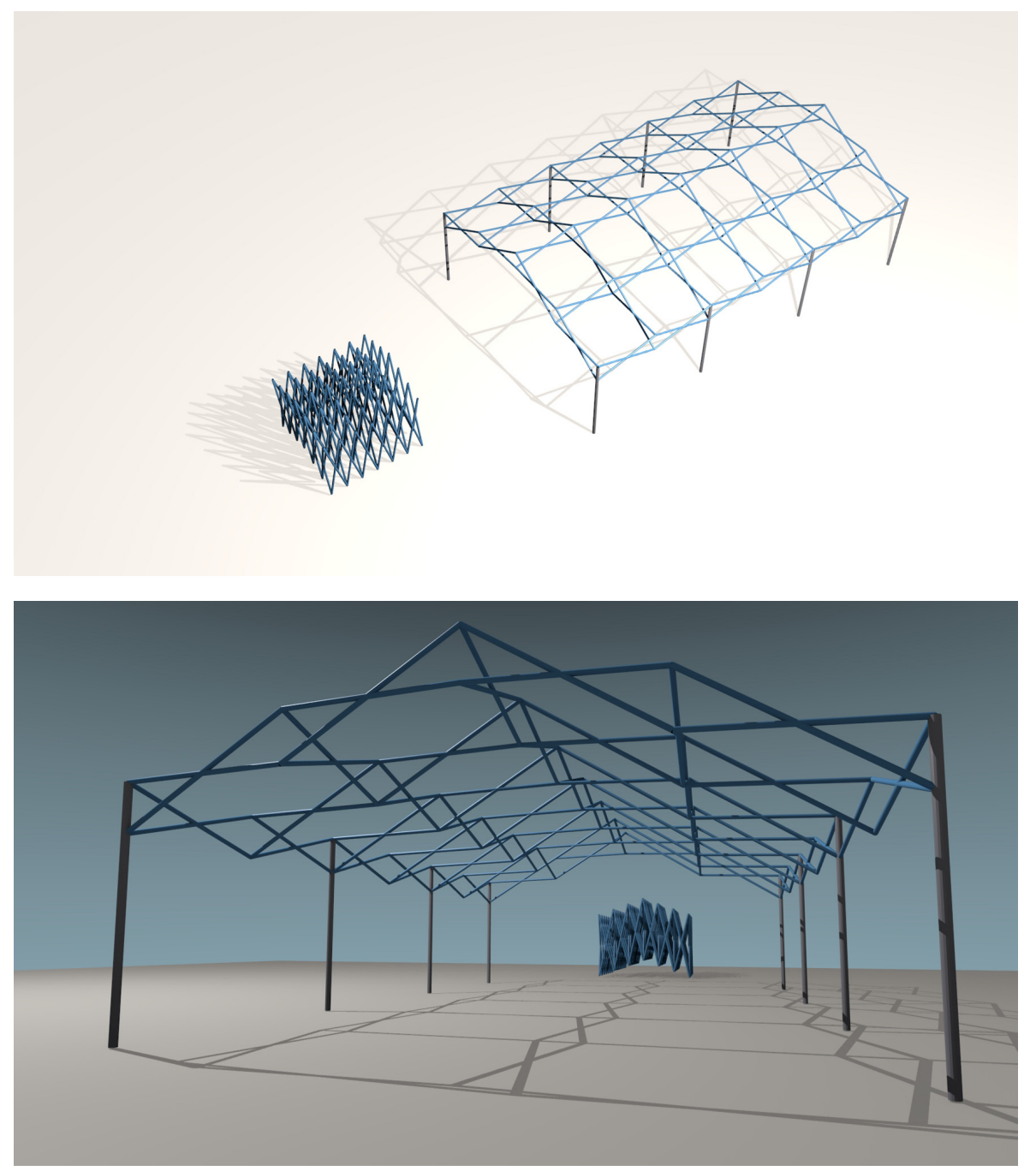

10 Cubierta a dos aguas al comienzo del despliegue y en posición final.

\section{Cubierta a dos aguas.}

10. Gable roof at the beginning of the deployment and in the final position.

\section{Gable roof.}


soluciones basadas en la triangulación geodésica de la esfera o en cúpulas de gajos, generalmente seis, lo que forma una malla hexagonal ${ }^{29}$. También se han propuesto otras soluciones basadas en una planta triangular. En cuanto a las cúpulas de módulo cuadrado, todas las propuestas se basan en cúpulas vaídas que permiten cubrir recintos cuadrados o rectangulares. Estos tipos de cúpulas han sido analizados en diversas publicaciones, por lo que únicamente nos limitaremos a citarlas ${ }^{30}$.

Sin embargo, un tipo específico como es la cúpula piramidal ha sido escasamente estudiado. Es posible que la razón de ello sea que para grandes luces precisa para limitar sus deformaciones un zunchado perimetral de cierta entidad, generalmente con cables, pero para luces reducidas la cubierta textil es suficiente. Esto permite su uso generalizado precisamente en el tipo de edificaciones que es objeto del presente artículo.

La eficacia estructural de estas cúpulas mejora cuando apoyan sobre mástiles perimetrales, como en las cubiertas de dos aguas. Son posibles dos formas de erección, que normalmente dependerán de las condiciones de cada caso. Es posible desplegar la malla en el suelo y hacer un izado posterior hasta su posición definitiva (Fig. 12). También es posible plegar la malla incluyendo los mástiles en el paquete, puesto que normalmente el paquete plegado tiene una altura no muy diferente a la de los mástiles. Aumenta un poco su altura, pero puede ser más fácil de erigir (Fig. 13). geodesic triangulation of the sphere or on a set of segments, usually six, giving rise to a hexagonal mesh ${ }^{29}$. In addition, another solutions based on a triangular plan have also been proposed. In the second group -domes based on squared modules-, all the proposals correspond to sailor's vaults covering plans square or rectangular in shape. Since these types of domes have been analysed in various publications, they will only be mentioned $^{30}$.

Despite this, the pyramidal dome is a specific case that has been poorly studied, perhaps due to the fact that for large spans its deformations must be limited using a perimeter ring of not a little size, usually solved by cables. Nevertheless, for small spans, the collaboration of the textile cover is enough to solve the problem, which allows the widespread use of these solutions in the type of buildings studied on this article.

The structural efficiency of these domes is improved by supporting them on perimeter masts, as in the case of gable roofs. These cupolas can be erected in two ways, depending on the conditions of each case: it is possible to deploy the mesh on the ground and make a subsequent hoist to its final position (Fig. 12), but it is also possible to fold the mesh including the masts in the package - normally the folded package has a height similar to that of the masts - with which although it increases its height a little, its erection is usually simpler (Fig. 13).
12. Fases de despliegue de una cúpula piramidal de base hexagonal desplegada en el suelo y elevada.

12. Phases of deployment of a pyramidal dome with hexagonal base deployed on the ground and hoisted.

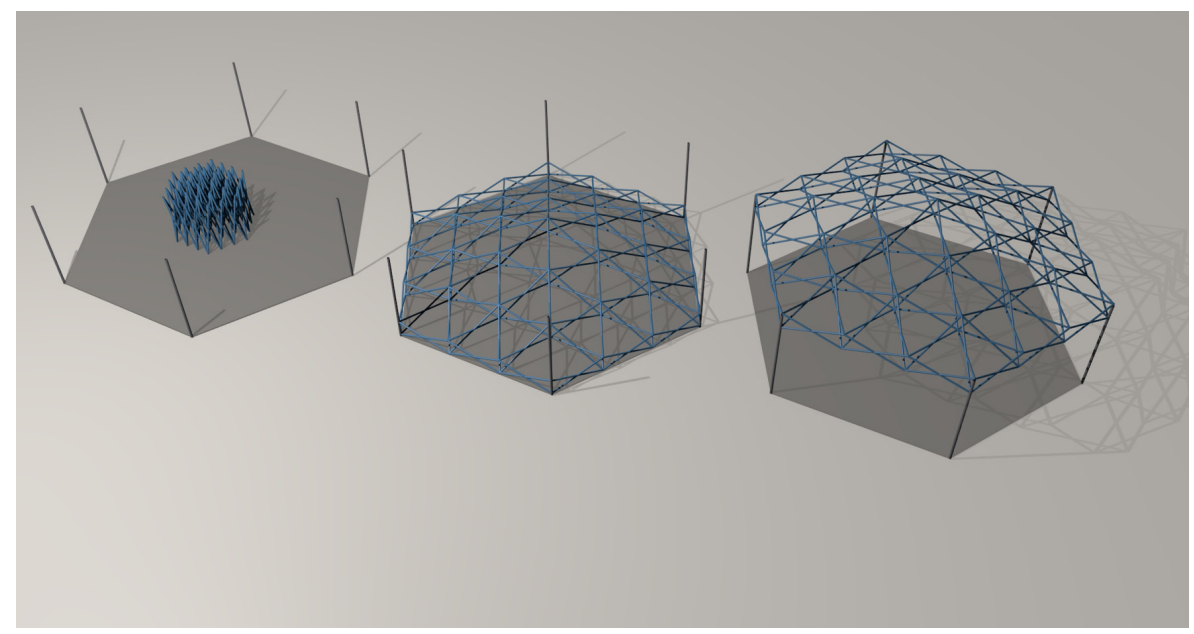




\section{Conclusiones}

Las estructuras desplegables resuelven muy adecuadamente aquellos usos ocasionales en los que sean determinantes las condiciones de rapidez de puesta en obra, entre los que se encuentran los usos festivos, tanto para luces medias como pequeñas. Este mismo tipo de estructuras constituye también una buena solución para muchos tipos de edificaciones de emergencia, cuyas prestaciones y luces son similares.

En este artículo se exponen una serie de soluciones basadas en módulos de despliegue oblicuo, hasta ahora insuficientemente estudiados. En su posición de plegado el paquete de barras tiene una longitud superior a la de los módulos rectos o curvos, pero permite una solución muy sencilla para cubiertas inclinadas, muy adecuadas para climas lluviosos. Las soluciones propuestas son sombrillas, cubiertas a dos aguas y cubiertas piramidales.

Las sombrillas desplegables son estructuras sencillas y útiles. Además de los módulos convencionales, se proponen módulos en paraboloide hiperbólico, cuya unión permite superficies quebradas, arquitectónicamente más interesantes y con una buena evacuación de aguas.

Los módulos oblicuos permiten un sencillo diseño de cubiertas a dos aguas y piramidales. Con una adecuada fijación sobre los mástiles de apoyo se pueden conseguir estructuras muy resistentes, que con escaso peso son capaces de cubrir luces medias.

\section{Conclusions}

The deployable structures solve very appropriately those occasional uses demanding a quick putting into service. Among these ones are the festive uses, with buildings of medium and small spans, and also plenty of the emergency buildings, whose requirements and spans are similar.

This paper presents several solutions based on oblique deployment modules, until now insufficiently studied. In its folded position, the bundle of bars has a length greater than the one of straight or curved modules, but allows a very simple solution for sloped roofs, very suitable for rainy climates. The proposed solutions are umbrellas, gabled roofs and pyramidal domes.

The deployable umbrellas are simple and useful structures. In addition to the conventional ones, modules for hyperbolic paraboloid surfaces are proposed, when they are joined together create angulated surfaces, architecturally more interesting and with a good water evacuation.

The oblique modules allow a simple design of gable roofs and pyramids. With a suitable fixation on the support masts, very resistant structures can be obtained, which with low weight are able to cover medium spans.

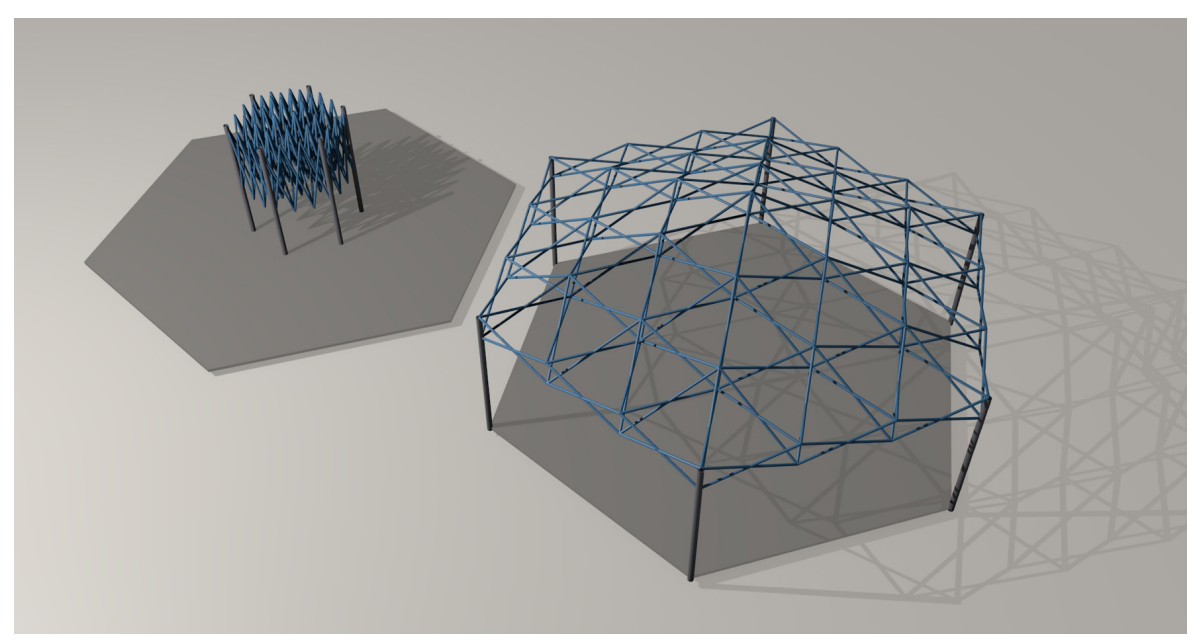

13. Fases de despliegue de una cúpula piramidal desplegada sobre mástiles.

13. Phases of deployment of a pyramidal dome deployed on mast. 
El sistema permite desplegar la cubierta en el suelo, colocar el material de cubierta y luego izar la cubierta completa sobre los mástiles de apoyo. Pero también es posible traer la cubierta completamente montada con los mástiles y una cubierta textil y desplegarla completamente. En el artículo se exponen las condiciones necesarias para el plegado de la cubierta textil y los sistemas de izado.

\section{Notas}

1. Construcciones desplegables y modulares para situaciones de catástrofe humanitaria (CODEMOSH), de referencia BIA2016-79459-R (MINECO).

2. F. Escrig, J. Sánchez y J.P. Valcárcel, "Foldable structures with textil cover," en 6th International Techtextil Symposium for Technical Textiles and TextileReinforced Materials (Frankfurt am Main, 1994).

3. S. Toshiaki, Extending/contracting-type tent structure (Patente P202-12780, 2000).

4. J. Pérez-Valcárcel y F. Escrig, "Pioneering in Expandable Structures: the 'Madrid I' Notebook by Leonardo da Vinci," Bulletin of the International Association for Shell and Spatial Structures, 35, no. 114 (1994): 33-45.

5. Emilio Pérez Piñero, "Estructures reticulées," L'Architecture d'Aujourd'hui no. 141 (1968): 76-81.

6. F. Candela, E. Pérez Piñero, S. Calatrava, F. Escrig y J. Pérez-Valcárcel, Arquitectura transformable (Sevilla: E.T.S.A., 1992).

7. F. Escrig y J. Pérez-Valcárcel, "Geometry of Expandable Space Structures," International Journal of Space Structures, 8, no. 2 (1993): 71-84.

8. F. Escrig y J. Sánchez, Estructura plegable de malla para la cubrición de recintos (Patente 2158787 A1, 1999).

9. C. Hoberman, Reversibly expandable doubly-curved truss structure (US Patent no. 4,942,700, 1992);

C. Hoberman, "The art and science of folding structures," Sites no. 24 (1992): 34-53.

10. C.J. Gantes, Deployable Structures: Analysis and Design (Southampton \& Boston: WIT Press, 2001).

11. Z.You y S. Pellegrino, "Foldable bar structures," International Journal of Solids Structures, 34, no. 15 (1997): 1825-1847

12. S. Pellegrino, Deployable Structures (New York Springer-Verlag Wien, 2001).

13. E. Pérez Belda y C. Pérez Almagro, "The deployable architecture commemorates the 25 years of peace. 50 th Anniversary of Emilio Pérez Piñero's
The system lets to unfold the grid on the ground, to place the cover material on it and then to raise the entire roof over the supporting masts. But it is also possible to bring the mesh completely assembled with the masts and the fabric cover and then deploy it completely. The article describes the necessary conditions for the textile cover folding and the lifting systems.

\section{Notes}

1. Construcciones desplegables y modulares para situaciones de catástrofe humanitaria (CODEMOSH), de referencia BIA2016-79459-R (MINECO).

2. F. Escrig, J. Sánchez y J.P. Valcárcel, "Foldable structures with textil cover," en 6th International Techtextil Symposium for Technical Textiles and TextileReinforced Materials (Frankfurt am Main, 1994).

3. S. Toshiaki, Extending/contracting-type tent structure (Patente P202-12780, 2000).

4. J. Pérez-Valcárcel y F. Escrig, "Pioneering in Expandable Structures: the 'Madrid I' Notebook by Leonardo da Vinci," Bulletin of the International Association for Shell and Spatial Structures, 35, no. 114 (1994): 33-45.

5. Emilio Pérez Piñero, "Estructures reticulées," L'Architecture d'Aujourd'hui no. 141 (1968): 76-81.

6. F. Candela, E. Pérez Piñero, S. Calatrava, F. Escrig y J. Pérez-Valcárcel, Arquitectura transformable (Sevilla: E.T.S.A., 1992).

7. F. Escrig y J. Pérez-Valcárcel, "Geometry of Expandable Space Structures," International Journal of Space Structures, 8, no. 2 (1993): 71-84.

8. F. Escrig y J. Sánchez, Estructura plegable de malla para la cubrición de recintos (Patente 2158787 A1, 1999).

9. C. Hoberman, Reversibly expandable doubly-curved truss structure (US Patent no. 4,942,700, 1992);

C. Hoberman, "The art and science of folding structures," Sites no. 24 (1992): 34-53.

10. C.J. Gantes, Deployable Structures: Analysis and Design (Southampton \& Boston: WIT Press, 2001).

Z.You y S. Pellegrino, "Foldable bar structures," International Journal of Solids Structures, 34, no. 15 (1997): 1825-1847

12. S. Pellegrino, Deployable Structures (New York: Springer-Verlag Wien, 2001).

13. E. Pérez Belda y C. Pérez Almagro, "The deployable architecture commemorates the 25 years of peace. 50 th Anniversary of Emilio Pérez Piñero's 
Pavilion” EGA no. 28 (2016): 146-155, https://doi. org/10.4995/ega.20166307.

14. Carlos H. Hernández Merchán, "Deployable Structures," en International Conference on Mobile and Rapidly Assembled Structures, MARAS'91, ed. P.S. Bulson (Southampton: Computational Mechanical Publications, 1991), 237-248.

15. F. Escrig y J. Pérez-Valcárcel, "Deployable Cover on a Swimming Pool in Seville". Bulletin of the International Association for Shell and Spatial Structures 37 no. 120 (1996): 39-70.

16. Niels De Temmerman, Design and Analysis of Deployable Bar Structures for Mobile Architectural Applications (Ph. D. Thesis, Brussel: Vrije Universiteit, 2007).

17. J. Begiristain Mitxelena, XXX, Sistemas estructurales desplegables para infraestructuras de intervención urbana autoconstruidas (Ph. D. Thesis, Donostia: Universidad del País Vasco, 2015).

18. O. Popovič y D. Sang-Hoon, "Reciprocal Frames (RFs) Used for Quick-built Deployable Emergency Shelters," en Proceedings of the International Association for Shell and Spatial Structures (IASS) Symposium, eds. J.B. Obrębski \& R. Tarczewski (Wroclaw, Poland: IASS, 2013), 1-7.

19. K. Atake, "ATAKE's structure- new variations of the scissors technique," en Third International Conference on Mobile and Rapidly Assembled Structures, MARAS III, eds. C.A. Brebbia \& F. Escrig, (Madrid: WIT Press, 2000), 143-154.

20. D. S-H Lee, O. Popovic Larsen y S-D Kim, "Study of the connection joint for scissor-type deployable structure for the possible application in emergency evacuation shelter." en Proceedings of the First Conference Transformables 2013. In the Honour of Emilio Perez Piñero, eds. F. Escrig \& J. Sánchez (Sevilla: Starbooks, 2013), 1-5.

21. K. Ishii, Structural Design of Retractable Roof Structures (Southampton: WIT Press, 2000).

22. E. Rivas Adrover, Deployable Structures (London: Laurence King Publishing, 2015).

23. F. Escrig y J. Pérez-Valcárcel, "Estructuras espaciales desplegables curvas,” Informes de la Construcción no. 393(Enero- Febrero 1988): 53-71.

24. L. Sánchez-Cuenca, "Geometric models for expandable structures," en Second International Conference on Mobile and Rapidly Assembled Structures II, MARAS'96, eds. F. Escrig \& C.A. Brebbia (Sevilla: Computational Mechanical Publications, 1996), 93102.

25. J.P. Valcárcel, F. Escrig, J. Estévez y E. Martín, "Expandable Triangular Cylindrical Vaults," en Congreso Internacional de Métodos Numéricos en Ingenieria y Ciencias Aplicadas (Concepción, Chile, Noviembre 1992), 1: 327-336.

26. J. Pérez-Valcárcel, F. Escrig, E. Martín y M. Freire, "Expandable Structures with Self-folding Textile Cover," en Mobile and Rapidly Assembled Structures,
Pavilion” EGA no. 28 (2016): 146-155, https:// doi.org/10.4995/ega.20166307.

14. Carlos H. Hernández Merchán, "Deployable Structures," en International Conference on Mobile and Rapidly Assembled Structures, MARAS'91, ed. P.S. Bulson (Southampton: Computational Mechanical Publications, 1991), 237-248.

15. F. Escrig y J. Pérez-Valcárcel, "Deployable Cover on a Swimming Pool in Seville". Bulletin of the International Association for Shell and Spatial Structures 37 no. 120 (1996): 39-70.

16. Niels De Temmerman, Design and Analysis of Deployable Bar Structures for Mobile Architectural Applications (Ph. D. Thesis, Brussel: Vrije Universiteit, 2007).

17. J. Begiristain Mitxelena, $X X X$, Sistemas estructurales desplegables para infraestructuras de intervención urbana autoconstruidas (Ph. D. Thesis, Donostia: Universidad del País Vasco, 2015).

18. O. Popovič y D. Sang-Hoon, "Reciprocal Frames (RFs) Used for Quick-built Deployable Emergency Shelters," en Proceedings of the International Association for Shell and Spatial Structures (IASS) Symposium, eds. J.B. Obrębski \& R. Tarczewski (Wroclaw, Poland: IASS, 2013), 1-7. 19. K. Atake, "ATAKE's structure- new variations of the scissors technique," en Third International Conference on Mobile and Rapidly Assembled Structures, MARAS III, eds. C.A. Brebbia \& F. Escrig, (Madrid: WIT Press, 2000), 143-154.

20. D. S-H Lee, O. Popovic Larsen y S-D Kim, "Study of the connection joint for scissor-type deployable structure for the possible application in emergency evacuation shelter." en Proceedings of the First Conference Transformables 2013. In the Honour of Emilio Perez Piñero, eds. F. Escrig \& J. Sánchez (Sevilla: Starbooks, 2013), 1-5.

21. K. Ishii, Structural Design of Retractable Roof Structures (Southampton: WIT Press, 2000).

22. E. Rivas Adrover, Deployable Structures (London: Laurence King Publishing, 2015).

23. F. Escrig y J. Pérez-Valcárcel, "Estructuras espaciales desplegables curvas," Informes de la Construcción no. 393(Enero- Febrero 1988): 53-71. 24. L. Sánchez-Cuenca, "Geometric models for expandable structures," en Second International Conference on Mobile and Rapidly Assembled Structures II, MARAS'96, eds. F. Escrig \& C.A. Brebbia (Sevilla: Computational Mechanical Publications, 1996), 93102.

25. J.P. Valcárcel, F. Escrig, J. Estévez y E. Martín, "Expandable Triangular Cylindrical Vaults," en Congreso Internacional de Métodos Numéricos en Ingeniería y Ciencias Aplicadas (Concepción, Chile, Noviembre 1992), 1: 327-336.

26. J. Pérez-Valcárcel, F. Escrig, E. Martín y M. Freire, "Expandable Structures with Self-folding Textile Cover," en Mobile and Rapidly Assembled 
MARAS'91, ed. P.S. Bulson (Southampton: Computational Mechanical Publications, 1991), 273-295.

27. Michael Barnes, Widespan Roof Structures (Londres: Thomas Telford, 2000), 15, https://doi org/10.1680/wrs.28777.fm

28. F. Escrig y J. Pérez-Valcárcel, "Great Size Umbrellas solved with Expandable Bar Structures," en First International Conference on Ligthweight Structures in Architecture, LSA 86, eds. M. Burgess \& M. De Bono (Sydney: University of New South Wales, 1986), 676-683.

29. J. Pérez-Valcárcel, F. Escrig, J. Estévez y E. Martín, "Large Span Expandable Domes," en Internacional Conference on Innovative Large Span Structures, eds. N.K. Srivastava, A.N. Sherbourne y J. Roorda (Montreal: The Canadian Society for Civil Engineering, 1992), 2: 619-630.

30. F. Escrig y J. Pérez-Valcárcel, "Geometry of Expandable Space Structures” International Journal of Space Structures 8 no. 2(1993): 71-84.

\section{Procedencia de las ilustraciones}

Figs. 01, 03-13. Propiedad de los autores

Fig. 02. proviene del Códice de Madrid I, con autorización de la Biblioteca Nacional

\section{Agradecimientos}

Este estudio forma parte del proyecto de investigación "Construcciones desplegables y modulares para situaciones de catástrofe humanitaria, CODEMOSH", financiado por el Ministerio de Economía y Competitividad (MINECO) del Reino de España de referencia BIA2016-79459-R

\section{Sobre los autores}

Juan Bautista Pérez Valcárcel es Dr. arquitecto y físico. Catedrático de estructuras de la ETSA de A Coruña. Ha desarrollado una amplia investigación en diversos campos y específicamente sobre estructuras desplegables.

juan.pvalcarcel@udc.es

Manuel Freire Tellado: Arquitecto (1989). Doctor Arquitectura (2001) ETSA Coruña. 2o Premio Nacional Terminación Estudios y Premio COAG PFC (1990). Máster Proyectos Arquitectónicos CSA Madrid (1992). Profesor en la Universidade da Coruña (1991-2019).

manuel.freire.tellado@udc.es

Manuel Muñoz Vidal: Arquitecto (1988) y Doctor Arquitecto (2001) ETSA Coruña. Profesor Universidade da Coruña (1990-2019). manuel.munoz@udc.es
Structures, MARAS'91, ed. P.S. Bulson (Southampton: Computational Mechanical Publications, 1991), 273-295. 27. Michael Barnes, Widespan Roof Structures (Londres: Thomas Telford, 2000), 15, https://doi. org/10.1680/wrs.28777.fm

28. F. Escrig y J. Pérez-Valcárcel, "Great Size Umbrellas solved with Expandable Bar Structures," en First International Conference on Ligthweight Structures in Architecture, LSA 86, eds. M. Burgess \& M. De Bono (Sydney: University of New South Wales, 1986), 676-683.

29. J. Pérez-Valcárcel, F. Escrig, J. Estévez y E. Martín, "Large Span Expandable Domes," en Internacional Conference on Innovative Large Span Structures, eds. N.K. Srivastava, A.N. Sherbourne y J. Roorda (Montreal: The Canadian Society for Civil Engineering, 1992), 2: 619-630.

30. F. Escrig y J. Pérez-Valcárcel, "Geometry of Expandable Space Structures" International Journal of Space Structures 8 no. 2(1993): 71-84.

\section{Source of illustration}

Figs. 01, 03-13 Property of the authors.

Fig 02 is taken from the Madrid I Codex by Leonardo da Vinci, with authorization from the National Library of Spain.

\section{Acknowledgments}

This study belongs to the research project "Deployable and modular constructions for situations of humanitarian catastrophe, CODEMOSH”, funded by the Ministry of Economy and Competitiveness (MINECO) of the Kingdom of Spain, with the reference BIA2016-79459-R.

\section{About the authors}

Juan Pérez Valcárcel is Dr. architect and degree in Physical Sciences. Full professor of structures in Coruña. He has developed extensive research in various fields and specifically on expandable structures.

juan.pvalcarcel@udc.es

Manuel Freire Tellado: Architect (1989). Ph.D. Architect (2001) ETSA Coruña. 2nd National Award of Completion Studies and COAG PFC Award (1990). Master's Degree in Architectural Projects CSA Madrid (1992). Professor at University of A Coruña (1991-2019).

manuel.freire.tellado@udc.es

Manuel Muñoz Vidal: Architect (1988) \& Ph.D. Architect (2001) ETSA Coruña. Lecturer Universidade da Coruña (1990-2019). manuel.munoz@udc.es 